\title{
EMERGENCY CARE UNITS (UPA) 24H: THE NURSES' PERCEPTION
}

\author{
Saionara Nunes de Oliveira1, Bianca Jacqueline Ramos², Marina Piazza ${ }^{3}$, Marta Lenise do Prado ${ }^{4}$, Kenya \\ Schmidt Reibnitz ${ }^{5}$, Adalbi Cilonei Souza ${ }^{6}$
}

${ }^{1}$ Master's Degree Post-graduate Program in Nursing (PEN) Universidade Federal de Santa Catarina (UFSC). Substitute Professor of the Department of Nursing UFSC. Grant-funded scholar of the National Council for Technological and Scientific Development (CNPq). Florianópolis, Santa Catarina, Brasil. E-mail: saionaranunes@gmail.com

${ }^{2}$ RN. Student on the Integrated Multi-professional Residency in Health of the UFSC Teaching Hospital. Florianópolis, Santa Catarina, Brasil. E-mail: biancajramos@yahoo.com.br

${ }^{3}$ RN. UFSC. Florianópolis, Santa Catarina, Brasil. E-mail: maripiazza18@hotmail.com

${ }^{4}$ Ph.D. in Philosophy of Nursing. Associate Professor of the Department of Nursing, PEN/UFSC. CNPq researcher. Florianópolis, Santa Catarina, Brasil. E-mail: mpradop@ccs.ufsc.br

${ }^{5}$ Ph.D. in Nursing. Full Professor of the Department of Nursing and of PEN/UFSC. Florianópolis, Santa Catarina, Brasil. E-mail: kenya@nfr.ufsc.br

${ }^{6}$ M.A. in Nursing. RN, Florianópolis Municipal Health Department. Florianópolis, Santa Catarina, Brasil. E-mail: adalbi@ hotmail.com

\begin{abstract}
This study aimed to describe the nurses' perception regarding the Emergency Care Units. It is descriptive research with a qualitative approach. The study participants were 25 nursing professionals from the Emergency Care Unit of a municipality in Santa Catarina who voluntarily accepted to participate in the study. The data were collected through interviews and were submitted to the operative proposal for analysis of qualitative data. The results show the professionals' understanding in relation to the purpose of these units, but indicate the incorrect way that this service is being used by the population; a fact that - added to the lack of materials, standardization of procedures, human resources and training - hinders the work process. It is suggested that continuing education may be used as a means for articulating the team and the search for quality work.
\end{abstract}

DESCRIPTORS: Nursing. Medical emergency services. Emergency nursing.

\section{UNIDADE DE PRONTO ATENDIMENTO - UPA 24H: PERCEPÇÃO DA ENFERMAGEM}

RESUMO: O objetivo do estudo foi descrever a percepção da enfermagem sobre as Unidades de Pronto Atendimento. Trata-se de uma pesquisa descritiva de abordagem qualitativa. Os participantes do estudo foram 25 profissionais de enfermagem das Unidades de Pronto Atendimento de um município de Santa Catarina que, voluntariamente, aceitaram participar da pesquisa. Os dados foram coletados através de entrevistas e submetidos à proposta operativa de análise de dados qualitativos. Os resultados demonstram a compreensão dos profissionais sobre a finalidade dessas unidades, mas apontam para a forma equivocada que o serviço vem sendo utilizado pela população; fato que, somado à falta de materiais, padronização de procedimentos, recursos humanos e capacitações, dificulta o processo de trabalho. Sugere-se que a educação permanente possa ser utilizada como forma de articulação da equipe na busca por um trabalho de qualidade.

DESCRITORES: Enfermagem. Serviços médicos de emergência. Enfermagem em emergência.

\section{UNIDAD DE CUIDADOS DE EMERGENCIA - UPA 24H: PERCEPCIÓN DE ENFERMERÍA}

RESUMEN: El objetivo de este estudio fue describir la percepción de la enfermería en las Unidades de Cuidados de Emergencia. Esta es una investigación con enfoque cualitativo, descriptivo. Los participantes del estudio fueron 25 profesionales de enfermería de las Unidades de Cuidados de Emergencia de una ciudad de Santa Catarina que voluntariamente aceptaron participar. Los datos fueron recolectados a través de entrevistas y sometidos a la propuesta de análisis operativa de los datos cualitativos. Los resultados demuestran la comprensión de los profesionales sobre el propósito de estas unidades, pero señalan el camino equivocado con que el servicio está siendo utilizado por la población, además del hecho de que la falta de materiales, normalización de los procedimientos, recursos humanos y capacitaciones, perturba el proceso de trabajo. Se sugiere que la educación continua se puede utilizar como una articulación del equipo en la búsqueda de un trabajo de calidad.

DESCRIPTORES: Enfermería. Servicios médicos de emergencia. Enfermería de urgencia. 


\section{INTRODUCTION}

The Brazilian health system is structured in three complementary hierarchical levels of health care - Primary Care, Medium complexity, and High complexity. ${ }^{1}$ Each one of these components of the care network must participate in Emergency Care, respecting the limits of their complexity and resolutive capacity. It is hoped that the population needing attendance may be embraced at any level of care and referred to the other levels when the complexity of the care required exceeds the ser-

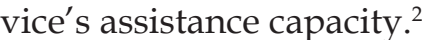

The lack of articulation between these departments, however, added to the increase in cases of accidents and urban violence in recent years, has caused overcrowding of hospital emergency services and emergency departments, transforming this area in one of the most problematic in the health system..$^{3-4}$

In this scenario, the Emergency Care Units (UPAs) have appeared as one of the strategies of the National Emergency Care Policy for the better organization of the care, articulation of the services, definition of flows and resolutive referrals. ${ }^{3}$ The strategy appears as one of the resolutive initiatives for the problem of overcrowding in hospital emergency services. ${ }^{5}$

The above-mentioned Units occupy the intermediate level of complexity, between the Primary Healthcare Centers (Primary Care) and Medium and High complexity, integrating the Pre-Hospital Stabilization Site Network. Created in 2002, the proposal was based in successful experiences in cities such as Campinas (in the state of São Paulo), Curitiba (Paraná), Belo Horizonte (Minas Gerais) and Rio de Janeiro (State of Rio de Janeiro). ${ }^{6-7}$

These must function 24 hours a day, undertaking triage with risk classification, providing resolutive attendance to patients affected by acute conditions or chronic conditions in acute phases, and low complexity cases, at night and on weekends, when the primary care network and the Family Health Strategy are not active; in this way, they are also a place for stabilization of the critically-ill patient for the Mobile Pre-Hospital Attendance Service (Ambulance Service), and construct consistent and effective flows of referral and counter-referral with other health institutions and services of the local-regional system. ${ }^{8}$

Triage undertaken with risk classification, in accordance with Ministerial Ordinance n. 2048/02, must be undertaken by a trained, degree-level professional, and must respect emergency assessment protocols, prioritizing the more serious cases for preferential attendance. $^{8}$

Ministerial Ordinance $n^{\circ} .1020$, of $13^{\text {th }}$ May $2009,{ }^{9}$ which establishes guidelines before the implantation of the Pre-hospital stabilization site component, which defines the UPAs' competencies and responsibilities, uses the term "embracement" instead of "triage", as stipulated by the Program Humaniza SUS, ${ }^{10}$ which understands triage as a practice of exclusion.

Among the professionals who work in the Units are: the coordinator or manager, a general practitioner, a pediatrician, a nurse, a nursing technician/auxiliary nurse, a radiology technician, a handyman, an administrative assistant and - when the unit has a laboratory - there must also be a biochemist, a laboratory technician, and a laboratory assistant. ${ }^{8}$

The nursing team is inserted in the new service, forming part of the team which embraces, assists, and participates in the process of referral and counter-referral of the patients. The care given in the area, however, remains insufficient in these professionals' training courses, consistent with what was noted by the National Emergency Care Policy itself. ${ }^{3}$

It was in this context that we sought, through this study, to describe the nursing team's perception regarding the UPAs, and to investigate the weak points and strengths found by the professionals inserted in this service.

\section{METHODOLOGY}

This is descriptive research, with a qualitative approach, undertaken in the UPAs of a municipality in Santa Catarina. The study was undertaken with all the professionals of the nursing team. A total of 25 professionals voluntarily accepted to participate; 11 of these were nurses, and 14 were nursing technicians. Visits were made to the study locale in order to get to know the professionals and to inform them about the research, emphasizing its objectives. The study was approved by the Federal University of Santa Catarina's Committee for Ethics in Research with Human Beings, under n. 1826/11. The participants signed the terms of consent, in accordance with Resolution 196/96. ${ }^{11}$ The members were identified in accordance with their position (' $\mathrm{N}$ ' for nurses and ' $\mathrm{T}$ ' for technicians), followed by the numerical order of the interview.

For data collection, we used individual interviews with a semistructured script, with the following guiding question: do you consider that 
Oliveira SN, Ramos BJ, Piazza M, Prado ML, Reibnitz KS, Souza AC

the work in the UPA differs from that of the other health care units, such as the primary care units or the hospital units? If so, in what aspect, and how? The interviews were recorded and transcribed, so as to ensure a detailed analysis of the material collected. They were later subjected to systematic analysis of the data through the operative proposal for analysis of qualitative data, which covers three phases. These were: a) pre-analysis: in this phase, the interviews were transcribed in full and, following that, successive readings were undertaken, highlighting the important ideas, the contradictions and similarities from the text; $b$ ) exploration of the material - after the pre-analysis, items highlighted in the text were grouped by similarities and were codified, with two representative categories emerging from the codes, namely: the nursing team's perception regarding the purpose of the UPAs; and the nursing team's perception regarding the work process in the UPAs; and c) the stage of treatment and interpretation. The significant categories were described and discussed in the light of the literature, based on which inferences were made regarding the data. ${ }^{12}$

\section{RESULTS AND DISCUSSION}

The analysis and interpretation of the data allowed us to identify two thematic groups: the nursing team's perception regarding the purpose of the UPAs and the nursing team's perception regarding the work process in the UPAs.

\section{The nursing team's perception regarding the purpose of the UPAs}

The UPAs, in the perception of the nursing professionals, have the purpose of being a place of fast attendance to serious cases, in which the objective of the assistance is to stabilize the situation, and to refer to hospitals when necessary. Here, patients were feeling pain at that moment; you have to act quickly, to control, to stabilize that patient (T11); They are not routine patients, there are situations of shootouts, stabbings, alcoholism, plenty of accidents. As a result, you end up providing first aid before they go to a hospital unit (T13).

This understanding meets what is stipulated by the Ministry of Health's National Emergency Care Policy ${ }^{3}$, which defines this on-site pre-hospital assistance as: "[...] assistance provided, at the primary level of care, to patients with acute situations, of a clinical, traumatic or psychiatric nature; which can lead to suffering, sequelae, or even death, stipulating appropriate attendance and/or transport to a hierarchized health service, regulated by and forming part of the State Emergency Service" 3:66

However, the cases attended in the UPAs in this study are frequently not classifiable as emergencies, creating a flow of patients which exceeds the service's capacity. Attendance to these cases becomes slow, causing stress, not only to the patient who is waiting, but also to the team which faces this situation on a daily basis, having to repeat, to each patient, the purpose of the UPAs. Here, it should be only emergencies, so that we can try to stabilize cases of more serious patients for referring them to hospital, but it's really different (N5); They [the population] come with ambulatory cases which should be treated there in the health clinic, such as mycosis, chigoe fleas (T10).

This reinforces what was shown by a study ${ }^{13}$ on the determinants for the demand for attendance in the UPAs in Belo Horizonte, in the state of Minas Gerais. The author shares the same analysis as other Brazilian and international authors, who show the fragmented way in which the health systems relate to each other, and how these units are being used for a wide variety of demands which do not constitute emergency attendance.

The professionals of the UPAs recognize that this is due to the health system's failure to absorb this demand in primary care, as we can ascertain in the accounts below: It's not the patient's fault, it's the system's fault, which can't embrace this patient. This guy even tried to go there [the health clinic], we can see the record in the medical records, but they told him there wasn't a doctor there, or that there wasn't a space in the diary for a consultation, or that he would have to schedule a consultation (N10); as it is difficult to access the health clinic, they come to the UPA, because they know that we can't deny attendance, so they find it easier to come here than to go there at the crack of dawn to get a ticket for attendance (T10).

This evidences the assertion that in times of need, pain or suffering people seek attendance where this is viable, regardless of the service's complexity, ${ }^{14}$ confirming this fact which occurs repeatedly on the shifts and is responsible for the significant increase of the workload in various emergency

* To attend a state health clinic in Brazil, it is necessary to go to the clinic early in the morning and queue to obtain - if one joins the queue early enough - a ticket entitling one to be attended later in the day. Translator's note. 
units. This compromises the quality of the care given, mainly affecting the team which undertakes the embracement with risk classification. This is an activity recognized by the nursing professionals of the UPAs as a differential of these units: I think this is a strong point of the UPAs, the risk classification (N1).

The overburden of work, therefore, ends up harming the quality of this approach, as may be ascertained in the following accounts: the question of embracement itself, of talking a little bit with the patient, while listening to him attentively-some nurses do that really, they embrace the patient as one should; while others, and I include myself among these, end up touching on issues more rapidly, listening to the patient's complaint and that's that. You can't spend 15 minutes with the patient in the room, knowing that there are 40 or 50 waiting outside (N10); all who deal with the public have the obligation to attend them well, I'm not saying that they don't; but, often, due to the excess of work, we could attend them better (T4).

The overload of work compromises the main role of Embracement with Risk Classification, which is qualified listening and the establishment of priorities for emergency attendance, guidance as to the role of primary care, and the importance of there being a link between the health centers and the patient. Triage with classification does not follow the logic of demand/time, as it will lose its focus, which is the speed, resolutive capacity, listening and demand referred onward to the Primary Healthcare Centers. ${ }^{13}$ The attendance to emergencies needs to be supported in all levels of care, each one within its resolutive limitations. Due to this, effective communication between Primary Care, UPA, the Ambulance Service (SAMU), Hospitals and other elements of the health system, such as the CAPSs (Psychosocial Care Centers), is essential for the efficiency of the service. ${ }^{15}$

The correct understanding of how the Health System is planned for attendance to emergencies needs to be clear for each profession involved in attending the service user. ${ }^{16}$

The study shows that, in spite of the professionals knowing the purpose of the UPAs, in accordance with the Brazilian National Emergency Care Policy, ${ }^{3}$ the reality experienced by them does not exactly follow what is stipulated by this policy, regarding the articulation with the other levels of care, as we can see in the following accounts: We resolve matters that should be done by the health clinic here, and hospital level issues as well (T9); It's different, because, really, it is a first aid station, but at the same time it functions as if it were a major health clinic; because we attend from emergencies through to basic health consultations (T12).

The lack of preparation by the institution which trains the staff is indicated as one of the reasons for the lack of effective knowledge of the UPAs' function in relation to the other levels of health care. University didn't prepare me for this. When I qualified, the UPA didn't exist, so the training was in a health clinic; and my university was very focused on primary or hospital care, but the main focus was on primary care, and this intermediate unit didn't exist (N1).

The National Emergency Care Policy already recognizes this shortcoming, so much so that it proposed to the managers, through its technical regulation, the creation of the Nuclei for Education in Emergency care (NEUs), as a tool capable of problematizing the reality of the service so that it could, based on that, undertaken a work of continuous education based on the context of this area in each level of care. ${ }^{3}$

It is foreseen in this policy that the NEUs must train the medical and nursing professionals who come to work in Nonhospital Emergency Care Units, given that the training is insufficient in this specific area within the undergraduate courses. ${ }^{3}$ The nuclei have, as their objectives and commitments, besides the promotion of the training of professionals involved in emergency attendance at all levels of care, the fostering of adjustment of the curriculum in the training institutions, and the implantation of teaching laboratories, involving, in an inter-institutional way, the training bodies and those which provide care. ${ }^{3}$ They must be organized "[...] under the administration of a board of directors, coordinated by the public manager of the SUS, having as elements: the state and municipal health departments, hospitals and specialist emergency services, police and fire service training colleges, higher education institutions for the training of personnel in the Health area, technical schools, and other sectors which provide help to the population, with both public and private characters, with municipal, regional or state coverage" $\mathrm{e}^{\prime 3: 134}$

In the context of this study, however, what was ascertained was a timid functioning of these nuclei, geared only towards the Ambulance Service (SAMU). ${ }^{17}$

\section{The nursing team's perception regarding the work process in the UPAs}

The nursing professionals of the UPAs identify the lack of standardization of the emergency 
attendance as an element which hinders the care. We began to do the triage, and they told us: 'you are going to have to triage the patient'; but, in the beginning, each one did to the triage in her own way, because each different shift had its own vision, there wasn't a rule, there was no training for us to go and do (N4); Sometimes, the same procedure is done differently by the professionals, there is no standardization and this is something which we miss, principally referent to the dilution of medication, to sterilization, and to conducts with the patient (T14).

One study indicates that the indicators of disorganization of the nursing services are related to the different professional conducts reflected in the lack of standardization of procedures, nonuse of a nursing care methodology and lack of norms and routines. ${ }^{18}$

Standardization of emergency nursing attendance, in this way, through protocols, allied with risk classification, can support the development of nursing interventions in a systematized and organized way, ensuring speed, safety and comprehensiveness of the care, which will be reflected in the quality of the care. ${ }^{19}$

One can perceive, however, an initiative for the creation of regulations for the UPAs in the account of one of the interviewees. First, we began to work, and doing the writing-up afterwards. I think it is a process which we are getting on top of, the norms, which we are putting down on paper (N2).

This shows that in spite of being discontented with the current work situation in these units, the professionals and the management recognize the lack of regulation as something which compromises the quality of the service. Other factors are also present in the interviewees' accounts as aspects which hinder the work, including the lack of physical structure and material and human resources. Lack of material. Sometimes, the space that we have there in the nursing station is small, there is a shortage of professionals (T1); There are problems on a daily basis, both physically - structurally, and technically; we have some professionals who work here who are not exactly from the emergency area (N2); We have to divide the work, the demand is heavy, we have few staff and have to know how to do administration duties, the management has to be on our side for us to succeed in mitigating this (N2).

One study identified the lack of material and human resources as factors which cause stress in the nursing teams, showing that scarcity of material causes feelings of irritation and tiredness in the professional, who needs to adapt to this context, seeking alternatives - which are not always found - for undertaking quality care. ${ }^{20}$
The authors also mention the lack of professionals, not simply numerically, but in their level of qualification, as an important stressor, given that professionals without experience in the care of critically-ill patients can overload the work of those who already possess greater professional experience.

It is important for health institutions to promote spaces for the team to discuss these problems; and that these times should promote the growth of the group, becoming an opportunity for undertaking continuous education. The professionals state, however, that the meetings in the UPAs are undertaken in order to resolve administrative problems and that there is no specific time for exchanging knowledge. They only call us to meetings for give us targets, for the functioning of the UPA and in relation to the workload, arriving late, relationship problems between the professionals, just for this (T10); We don't even manage monthly meetings, not even three-monthly, actually, we always try to have this guarantee of meetings, but when it happens, when it arrives at a limit where we cannot manage, then we have a meeting, to put out fires (T5); We talk, show, discuss what was done wrong, what is new or not, now the ABC has changed. We can do this sort of updating or refresher training, we don't have materials for practical lessons (N6).

The transformation of rules, concepts and limits in the work is only possible with the participation of all those involved, motivated by the wish to perform their role better, in a healthier, more organized and more committed way. ${ }^{21}$ The National Policy for Continuing Education in Health ratifies that this situation considers the valorization of the work process itself as a motivator for learning, capable of transforming the practice based on the discussions of the daily situations. ${ }^{22}$ Despite all these points raised, as elements which hinder the work in the UPAs, this service has characteristics which facilitate the professionals' lives, and which deserve to be highlighted even so as to justify their continuity in this level of care. Among the principal characteristics, we emphasize the working day of 12 hours followed by 48 hours off, the speed of the attendance, and the emergency attendances. What attracted me here was the hours, so that I could participate more in my son's life, as well as new knowledge, a new stage in my career (T5); I used to work in the health center and, as I am a state employee, the hours were conflicting, I wasn't managing. The UPA opened and I asked to be transferred there, because there I would work 12 hour shifts for the state (T3); It is calmer here, because when the shift finishes, the shift is over, and that's that. There's nothing to take 
home. This is what was of interest to me, because I was tired of working in the PSF (N3); I always wanted to work in emergency, I wanted to enter that area (T13).

It may be noted that the ease of conciliating working hours with personal life, and with other employment links ${ }^{* *}$, is an important factor for some professionals. The speed of the service, which makes the relationship with the patient more dynamic, is something positive, both for those who like dealing with emergencies because of a simple affinity with the area, and for those who prefer not to establish links with patients who require a dedication which extends outside the shift hours.

Another study ${ }^{23}$ undertaken with the nursing team of an emergency department revealed the team to have similar interests in working in these areas. The authors show that the possibility of conciliating the work with studies or other employment links, an affinity with emergencies, and the importance of the work for the health system, among others, were factors which influenced the choice to work in the UPAs.

\section{FINAL CONSIDERATIONS}

The understanding of the nursing team's perception regarding the UPAs, as a new service inserted in the emergency care network, is important from the point of view of the need which the service has to be integrated with the other levels of care for the success of the proposal of the PNAU.

The study demonstrated that the professionals from the nursing team see the UPAs as important places for fast and resolutive attendance for emergency cases; however, they call attention to the incorrect way in which the Units are being used, serving as gateways for outpatient cases which could be attended in the primary healthcare network.

The demand for fast attendance for cases which are not emergency is not specific to the units studied. This context is perceived in other Emergency Care Units in Brazil, as well as in studies undertaken in other countries. For this reason, greater support is necessary for Primary Care, ensuring adequate human resources and effective training for these professionals, such that the service may have resolutive capacity for those cases stipulated in the primary care policy.

This overburden of work, caused by the increased demand from patients seeking immediate attendance for cases which are not characterized as emergency, added to the Units' lack of material, physical structure, and human resources, impairs the speed and quality of the attendance. The lack of standardization of the attendance is also concerning, as it can result in problems related to patient safety, wastage of material, and conflicts in the team, among others. However, the professionals who work there - even with all the difficulties faced - like it and wish to remain there, for a variety of reasons. This facilitates the attempt to involve them in strategies for improving the service; management should pay attention to this aspect as an opportunity for change.

The study presents the nursing team's perception regarding the UPAs, raising situations in which continuous education could function as a strategy for bringing the team closer, and as an opportunity for growth, the resolution of conflicts, and participation in management. We understand that continuous education enters the scenario as an essential tool for these and other discussions. Nevertheless, further research needs to be undertaken in this context, so as to extend knowledge regarding this reality, given that this service was implanted recently and the number of scientific publications focusing on this level of care remains low.

\section{REFERENCES}

1. Ministério da Saúde (BR). Portal da Saúde: Média e Alta Complexidade. [acesso 2011 Jun 26]. Disponível em: http://portal.saude.gov.br/portal/sas/mac/ area.cfm?id_area $=828$

2. Garlet ER, Lima MADS, Santos JLG, Marques GQ. Organização do trabalho de uma equipe de saúde no atendimento ao usuário em situações de urgência e emergência. Texto Contexto Enferm [online]. 2009 Jun [acesso 2011 Jun 26]; 18(2):266-72. Disponível em: http:/ / www.scielo.br/scielo.php?script=sci_ arttext\&pid=S0104-07072009000200009\&lng=pt

3. Ministério da Saúde (BR). Política Nacional de Atenção às Urgências. Brasília (DF): MS; 2006.

4. O’Dwyer G. A gestão da atenção às urgências e o protagonismo federal. Cien Saude Colet [online]. 2010 Ago [acesso 2012 Jun 20]; 15(5):2395-404. Disponível em: http:/ / www.scielosp.org/pdf/csc/ v15n5/v15n5a14.pdf

5. Bittencourt RJ, Hortale VA. Intervenções para solucionar a superlotação nos serviços de emergência hospitalar: uma revisão sistemática. Cad. Saúde Pública [online]. 2009 Jul [acesso 2011 Jul 26];

\footnotetext{
** Due to low salaries, it is common in Brazil for nurses to work two shifts a day, sometimes in different institutions. Translator's note.
} 
25(7):1439-54. Disponível em: http://www.scielo. $\mathrm{br} /$ scielo.php?script $=$ sci_arttext\&pid $=$ S0102311X2009000700002\&lng=pt

6. Ministério da Saúde [página na Internet]. Brasília (DF): MS; 2010 [acesso 2010 Jun 26]. Disponível em: http://portal.saude.gov.br/portal/aplicacoes/ noticias/default.cfm?pg=dspDetalheNoticia\&id_ area $=124 \& C O \_$NOTICIA $=11150$

7. Almeida PF, Giovanella L, Mendonça MHM, Escorel S. Desafios à coordenação dos cuidados em saúde: estratégias de integração entre níveis assistenciais em grandes centros urbanos. Cad Saúde Pública [online]. 2010 Fev [acesso 2012 Jun 20]; 26(2):286-98. Disponível em: http:/ / www.scielo.br/scielo.php?script=sci_ arttext\&pid=S010211X2010000200008\&lng=en

8. Ministério da Saúde (BR). Portaria n. 2048/GM/MS de 05 de novembro de 2002: Aprova o regulamento técnico dos sistemas estaduais de urgência e emergência. Brasília (DF): MS; 2002.

9. Ministério da Saúde (BR). Portaria n. 1020/GM/ MS de 13 de maio de 2009: Estabelece diretrizes para a implantação do componente pré-hospitalar fixo para a organização de redes locorregionais de atenção integral às urgências em conformidade com a Política Nacional de Atenção às Urgências. Brasília (DF): MS; 2009.

10. Ministério da Saúde (BR). Secretaria-Executiva, Núcleo Técnico da Política Nacional de Humanização. HumanizaSUS - Acolhimento com avaliação e classificação de risco: um paradigma ético-estético no fazer em saúde. Brasília (DF): MS; 2004.

11. Ministério da Saúde (BR), Conselho Nacional de Saúde, Comissão Nacional de Ética em Pesquisa. Resolução n. 196 de 10 de outubro de 1996: diretrizes e normas regulamentadoras de pesquisa envolvendo seres humanos. Brasília (DF): MS; 1996.

12. Minayo MCS. O desafio do conhecimento: pesquisa qualitativa em saúde. $11^{\mathrm{a}}$ ed. São Paulo (SP): HucitecAbrasco; 2008.

13. Rocha AFS. Determinantes da procura de atendimento de urgência pelos usuários nas unidades de pronto atendimento da secretaria municipal de saúde de Belo Horizonte [dissertação]. Belo Horizonte (MG): Universidade Federal de Minas Gerais, Escola de Enfermagem; 2005.

14. Cecilio LCO. Modelos tecno-assistenciais em saúde: da pirâmide ao círculo, uma possibilidade a ser explorada. Cad Saúde Pública [online]. 1997 Jul-Set [acesso 2011 Jun 26]; 13(3):469-78. Disponível em: http://www.scielosp.org/pdf/csp/v13n3/0171.pdf
15. Lima JC, Rivera FJU. Redes de conversação e coordenação de ações de saúde: estudo em um serviço móvel regional de atenção às urgências. Cad Saúde Pública [online]. $2010 \mathrm{Fev}$ [acesso 2012 Jun 20]; 26(2): 323-36. Disponível em: http:/ / www. scielo.br/scielo.php?script=sci_arttext\&pid=S0102311X2010000200011\&lng=en

16. Garlet ER, Lima MADS, Santos JLG, Marques GQ. Finalidade do trabalho em urgências e emergências. Rev Latino-Am Enferm [online]. 2009 Ago [acesso 2012 Jun 20]; 17(4):535-40. Disponível em: http:/ / www.scielo.br/scielo.php?script $=$ sci arttext\&pid=S0104-11692009000400016\&lng=en

17. Santa Catarina [página na internet]. Núcleo de educação em urgência- NEU. [acesso 2011 Jun 26]. Disponível em: http:/ / neu.saude.sc.gov.br/index. php?option $=$ com_frontpage\&Itemid $=1$

18. Guerrero GP, Beccaria LM, Trevizan MA. Procedimento operacional padrão: utilização na assistência de enfermagem em serviços hospitalares. Rev Latino-Am Enferm [online]. 2008 [acesso 2011 Jun 26]; 16(6):966-72. Disponível em: http:/ / www.scielo.br/scielo.php?pid=S0104$11692008000600005 \&$ script $=$ sci_abstract\&tlng=pt

19. Ulbrich EM, Mantovani MF, Balduino AF, Reis BK. Protocolo de enfermagem em atendimento emergencial: subsídios para o acolhimento às vítimas. Cogitare Enferm [online]. 2010 Abr-Jun; [acesso 2011 Jun 26]; 15(2):286-92. Disponível em: http://ojs.c3sl.ufpr.br/ojs2/index.php/cogitare/ article/viewArticle/17863

20. Coronetti A, Nascimento ERP, Barra DCC, Martins JJ. O estresse da equipe de enfermagem na Unidade de Terapia Intensiva: o enfermeiro como mediador. Arq Cat Med [online]. 2006; [acesso 2011 Jun 26]; 35(4):36-43. Disponível em: http://www.acm.org. br/revista/pdf/artigos/394.pdf

21. Rodrigues R, Imai R, Ferreira W. Um espaço para o desenvolvimento interpessoal no trabalho. Psicol Estud [online]. 2001 Jul-Dez; [acesso 2011 Jun 26]; 6(2):123-7. Disponível em: http://www.scielo.br/ pdf/pe/v6n2/v6n2a17.pdf

22. Ministério da Saúde (BR). Política Nacional de Educação Permanente em Saúde. Série Pactos pela Saúde 2006, v. 9. Brasília (DF): MS; 2009.

23. Calderero ARL, Miasso AI, Corradi-Webster CM. Estresse e estratégias de enfrentamento em uma equipe de enfermagem de pronto atendimento. Rev Eletr Enf [online]. 2008; [acesso 2011 Jun 26]; 10(1):51-62. Disponível em: http://www.fen.ufg. br/revista/v10/n1/v10n1a05.httm 